\title{
HUBUNGAN TINGKAT PENDIDIKAN IBU DAN TINGKAT PENDAPATAN KELUARGA DENGAN STATUS GIZI ANAK PRASEKOLAH DAN SEKOLAH DASAR DI KECAMATAN GODEAN
}

\author{
Fardhiasih Dwi Astuti, Taurina Fitriya Sulistyowati \\ Fakultas Kesehatan Masyarakat, Universitas Ahmad Dahlan, Yogyakarta
}

\begin{abstract}
Background : Based on rank human development index (HDI), Indonesia is on order 109 of state, 174 far below the other asean countries. Factors dominated HDI developed by united nations development program (UNDP) is education, health, and economics. The third factor is very close to nutrition status of society. Based on the research basic health 2010, prevalence toddlers undernourishment ( weight less ) by 18.0 percents 4.9 percent with malnutrition and prevalence toddlers bony ( wasting ) is 13.3 percent. Riskesdas 2010 described inhabitant of consuming food under $70 \%$ of figure adequate nutrition that is recommended 2004 as many as 40,6 percent this situation many units which on a school-age child $(41.2 \%)$, adolescent ( 54.5 $\%$ ), and pregnant women ( $44.2 \%$ ), this will affect nutrition status.
\end{abstract}

Methods : This research was using crosssectional design.

Results : Obtained the status malnutrition $14.5 \%$, normal nutrition status $82,6 \%$ and nutrition status more $2.9 \%$. Relation nutrition status with the level of education mother p-value 0,471 , relation nutrition status with income $p$ value 0,136 .

Conclusion : These were no relationship between nutrition status and the level of education mother, and no relationship between nutrition status with income.

Keyword: education, income, nutrition status

\section{PENDAHULUAN}

Berdasarkan peringkat human development index (HDI), Indonesia berada pada tahun 2011 urutan 124 dari 187 negara, jauh di bawah negara ASEAN lainnya seperti Singapore 26, Brunei (33), Malaysia (61), Thailand (103) dan Filipina (112). Faktor-faktor yang menjadi penentu HDI yang dikembangkan oleh UNDP (United Nations Development Program) adalah pendidikan, kesehatan, dan ekonomi. Ketiga faktor tersebut sangat berkaitan dengan status gizi masyarakat ${ }^{1}$.

Hasil analisis data Susenas 2000 terhadap status gizi balita di Indonesia dengan menggunakan metode z-score baku WHO-NCHS, ditemukan gizi baik $72,02 \%$, KEP ringan/sedang 17,13\%, dan KEP berat 7,53\%. Adapun untuk wilayah Yogyakarta dengan metode z-score baku WHO-NCHS, ditemukan gizi baik $78,24 \%$, KEP ringan/sedang 12,84\%, dan KEP berat $4,73 \%$. Berdasarkan data tersebut dapat dikatakan bahwa kejadian KEP masih relatif tinggi di Indonesia ${ }^{1}$.

Berdasarkan hasil Riset Kesehatan Dasar tahun 2010, prevalensi balita kurang gizi (berat badan kurang) sebesar 18,0 persen diantaranya 4,9 persen dengan gizi buruk dan prevalensi balita kurus (wasting) adalah 13,3 persen. Riset Kesehatan Dasar/Riskesdas 2010, digambarkan penduduk mengkonsumsi makanan di bawah 70\% dari Angka Kecukupan Gizi (AKG) yang dianjurkan tahun 2004 sebanyak 40,6 persen Keadaan ini banyak dijumpai pada anak usia sekolah $(41,2 \%)$, remaja $(54,5 \%)$, dan ibu hamil $(44,2 \%){ }^{2}$ 
Gizi menjadi masalah yang penting bagi anak sekolah, karena gizi bisa mencerdaskan anak. Anak yang kekurangan gizi mudah mengantuk dan kurang bergairah yang dapat menganggu proses belajar di sekolah dan menurun prestasi belajarnya, daya pikir anak juga akan kurang, karena pertumbuhan otaknya tidak optimal $^{3}$. Banyak faktor yang mempengaruhi status gizi pada anak. Pola asupan makanan yang tidak seimbang pada anak usia sekolah dalam jangka waktu yang lama akan menyebabkan kurangnya gizi dalam tubuh. Anak usia sekolah sangat memerlukan asupan makanan yang seimbang untuk menunjang tumbuh kembangnya ${ }^{3}$. Peran orang tua sangat berpengaruh terutama pada ibu, karena seorang ibu berperan dalam pengelolaan rumah tangga dan berperan dalam mementukan jenis makanan yang akan dikonsumsi keluarganya. Hasil penelitian Hadivian dan Sylvia ${ }^{4}$, ada pengaruh pengetahuan, sikap praktek ibu tentang gizi dan pendapatan keluarga terhadap tingkat kecukupan energi dan protein anak balita. Hasil penelitian Lutviana dan Budiono $^{5}$ ada hubungan antara tingkat pendapatan dengan status gizi balita. Berdasarkan latar belakang diatas maka peneliti ingin mengetahui apakah ada hubungan tingkat pendidikan ibu dan pendapatan keluarga terhadap status gizi anak.

\section{METODE}

Penelitian ini merupakan penelitian analitik observational dengan rancangan crosssactional. Populasi dalam penelitian ini adalah anak prasekolah dan sekolah dasar Muhammadiyah di kecamatan Godean, Sleman. Sampel dalam penelitian ini adalah anak yang terpilih secara randem menjadi subjek penelitian. Jumlah sampel yang diambil berdasarkan penghitungan sampel size epiinfo dari populasi 746 respondent pada drajat kepercayaan 95\% didapatkan hasil sebesar 117 sampel. Penelitian ini menggunakan analisis diskriptif statistik dan hubungan antar variabel di uji dengan analisis regresi linier.

\section{HASIL PENELITIAN DAN PEMBAHASAN}

\section{A. Hasil Penelitian}

Penelitian ini dilakukan pada siswa-siswi TK ABA Jowah dan SD Muhammadiyah Sangonan IV dengan jumlah responden sebanyak 138 siswa. Responden pada penelitian ini 67 orang (48,6\%) merupakan laki laki, dan 71 orang $(51,4 \%)$ perempuan.

Tabel 1. Distribusi Status Gizi anak TK ABA Jowah dan SD Muhammadiyah Sangonan IV

\begin{tabular}{ccc}
\hline Status gizi & Frekuensi & Persentase (\%) \\
\hline Kurus & 20 & 14,5 \\
Normal & 114 & 82,6 \\
Overweight & 4 & 2,9 \\
Jumlah & 138 & 100 \\
\hline
\end{tabular}

Berdasarkan Tabel 1 diatas diketahui $82,6 \%$ status gizi responden adalah normal. 
Tabel 2. Distribusi tingkat pendidikan ibu di TK ABA Jowah dan SD Muhammadiyah Sangonan IV

\begin{tabular}{ccc}
\hline Pendidikan ibu & Frekuensi & Persentase (\%) \\
\hline Tidak sekolah & 1 & 0,7 \\
SD & 30 & 21,7 \\
SLTP & 36 & 26,1 \\
SLTA & 61 & 44,2 \\
Perguruan Tinggi/ D3 & 10 & 7,2 \\
\hline
\end{tabular}

Tingkat pendidikan ibu dari responden paling banyak adalah SLTA $44,2 \%$ (Table 2). Pendapatan keluarga responden minimal sebesar Rp $100.000,00$ dan maksimal sebesar Rp 9.000.000,00. Hasil analisis rata-rata pendapatan sebesar Rp 1.184.500,00.

Hasil analisis Person correlation hubungan antara status gizi dan pendapatan orang tua didapatkan $R=0.094$ dan $p$ value 0.136 . Hal ini menunjukkan bahwa tidak ada hubungan antara pendapatan orang tua dengan status gizi pada anak TK ABA Jowah dan SD Muhammadiyah Sangonan IV.

Pendapatan orang tua jika dikelompokan didapatkan sebagian besar berpendapatan rendah (kurang dari UMR Yogyakarta tahun 2012 yaitu Rp: 892.660 ) sebesar 76 orang $55,1 \%$, pendapatan sedang sebanyak 47 orang $(34,1 \%)$ dan yang berpendapatan tinggi sebanyak 15 orang $(10,9 \%)$.

Hasil Pearson correlation antara pendidikan dan status gizi didapatkan angka $-0,006$ dengan $p$ value 0,471 . Hal ini menunjukkan tidak adanya hubungan antara pendidikan ibu dengan status gizi di TK ABA Jowah dan SD Muhammadiyah Sangonan IV.

Hasil $R$ square dari pendapatan dan pendidikan 0,012, hal ini menunjukan pengaruh dari pendapatan dan pendidikan ibu hanya sebesar $1,2 \%$ terhadap status gizi pada TK ABA Jowah dan SD Muhammadiyah Sangonan IV.

\section{B. Pembahasan}

Berdasarkan Tabel 1 diketahui status gizi anak prasekolah dan sekolah dasar sebagian besar mempunyai status gizi yang normal (82,6\%). Hasil tersebut menunjukan bahwa sebagian besar responden telah mendapatkan kecukupan gizi dari makanan yang mereka konsumsi. Status gizi baik atau status gizi optimal terjadi bila tubuh memperoleh cukup zat-zat gizi yang digunakan secara efisien, sehingga memungkinkan pertumbuhan fisik, perkembangan otak, kemampuan kerja dan kesehatan secara umum pada tingkat semaksimal mungkin. ${ }^{6}$

Responden dengan status gizi yang kurang sebanyak $14,5 \%$. Status gizi kurang terjadi bila tubuh mengalami kekurangan satu atau lebih zat-zat gizi esensial. ${ }^{6}$ Responden dengan status gizi lebih hanya 4 anak $(2,9 \%)$. Status gizi yang lebih terjadi karena tubuh memperoleh zat-zat gizi dalam jumlah berlebihan. ${ }^{6}$

Jenjang pendidikan formal di Indonesia berdasarkan Peraturan Pemerintah RI No 66 tahun 2010 terbagi menjadi pendidikan dasar, pendidikan menengah, dan pendidikan tinggi. Berdasarkan Tabel 2 diketahui sebagian besar ibu dari responden berpendidikan menengah yaitu SMA sebanyak 44,2\%.

Hasil analisis tingkat pendidikan ibu dengan status gizi didapatkan probability sebesar 0,471 , menunjukan tidakadanya hubungan antara tingkat pendidikan ibu dengan status gizi anak di TK ABA Jowah dan SD 
Muhammadiyah Sangonan IV. Tidak adanya hubungan pendidikan dengan status gizi dapat dikarenakan perkembangan teknologi yang ada saat ini. Ibu dengan tingkat pendidikan rendah dengan adanya perkembangan teknologi saat ini dapat dengan mudah mengakses informasi dari berbagai media, sehingga mereka dapat meningkatkan pengetahuannya. Hasil penelitian ini sama dengan penelitian Linda, ${ }^{7}$ Edris ${ }^{8}$ yang menunjukan tidak adanya hubungan antara pendidikan ibu dengan status gizi pada anak.

Hasil penelitian Sari ${ }^{9}$ menunjukan adanya hubungan tingkat pengetahuan dengan status gizi balita. Pengetahuan yang baik akan mempengaruhi pola konsumsi makanan sehingga akan terjadi status gizi yang baik. Pengetahuan dapat diperoleh dari pendidikan formal maupun informal. Penelitian ini tingkat pendidikan tidak berhubungan dengan status gizi, meskipun pada penelitian lain tingkat pendidikan dapat mempengaruhi status gizi. Penelitian Kusumaningrum ${ }^{10}$ yang menunjukan adanya hubungan tingkat pendidikan dengan status gizi balita di Kecamatan Simo Boyolali.

Pendapatan keluarga responden paling rendah sebesar Rp: 100.000 dan tertinggi sebesar Rp: 9.000.000 dan rata-rata pendapatan Rp: 1.184.500. Pendapatan responden jika di kelompokkan, sebagian besar responden memiliki tingkat pendapatan yang rendah $55,1 \%$. Pendapatan pada penelitian ini dikriteriakan rendah jika kurang dari UMR Yogyakarta 2012 sebesar Rp: 892.660. Pendapatan keluarga sangat mempengaruhi terhadap konsumsi makanan sehari-hari. Apabila pendapatan rendah maka makanan yang dikonsumsi tidak mempertimbangkan nilai gizi, tetapi nilai materi lebih menjadi pertimbangan ${ }^{5}$.

Analisis hubungan tingkat pendapatan dengan status gizi pada penelitian ini didapatkan $p$-value 0,136 sehingga dapat disimpulkan bahwa tidak ada hubungan tingat pendapatan dengan status gizi pada anak TK ABA Jowah dan SD Muhammadiyah Sangonan IV. Penelitian ini berbeda dengan penelitian lain yang menujukkan adanya hubungan pendapatan dengan status gizi ${ }^{10,11}$ Pendapatan rendah mempengaruhi jumlah makanan yang dikonsumsi keluarga dan meningkatkan kemungkinan kerkenanya penyakit infeksi sehingga status gizinya rendah ${ }^{8}$.

Penelitian ini tidak menunjukan adanya hubungan antara pendapatan dengan status gizi pada anak dapat di karenakan pendapatan keluarga yang kurang dari UMR masih dapat mencukupi kebutuhan makanan keluarga sehingga status gizinya normal.

\section{SIMPULAN DAN SARAN}

\section{A. Simpulan}

Tidak ada hubungan antara tingkat pendidikan ibu dan pendapatan dengan status gizi anak prasekolah dan sekolah dasar Muhammadiyah di Kecamatan Godean Sleman.

\section{B. Saran}

Masih perlu adanya perhatian khusus dan pemberian makanan tambahan pada anak dengan status gizi kurus di TK ABA Jowah dan SD Muhammadiyah Sangonan IV. 


\section{DAFTAR PUSTAKA}

1. Akhmadi, Permasalahan Gizi di Indonesia, www.rajawana.com/artikel/kesehatan/384-permasalahan-gizi-di-indonesia.html 2009, diakses pada tanggal 23 Oktober 2011.

2. Badan. Perencanaan Pembangunan Nasional (Bappenas). Penyusunan indeks komposit perlindungan anak. Jakarta : Bappenas. 2010, www.bapenas.go.id/getfile-server/node/334 diakses pada tanggal 23 oktober 2011

3. Anindya, Kebutuhan Gizi Seimbang Anak Usia Sekolah, 2009, www.rajawana.com/artikel/kesehatan/384-kebutuhan-gizi-seimbang-usiasekolah.html diakses pada tanggal 23 Oktober 2011.

4. Hardivian, Sylvia Licha, Pengaruh Karakteristik lbu dan Pendapatan Keluarga Terhadap Tingkat Kecukupan Energi dan Protein Serta Status Gizi Anak Balita di Desa Suwawal Barat, Kecamatan Mlonggo, Kabupaten Jepara. 2003, www.eprint.undip.ac.id diakses 23 Agustus 2012.

5. Lutviana dan Budiono, Prevalensi dan determinan kejadian gizi kurang Pada balita (studi kasus pada keluarga nelayan di Desa bajomulyo kecamatan juwana kabupaten pati), Jurnal Kemas, vol 5 (2): 165 - 172, 2010.

6. Almatsier, S. Prinsip Dasar IImu Gizi. Jakarta : EGC. 2003.

7. Linda Ony, dan Hamal D.K., Hubungan pendidikan dan pekerjaan orangtua serta Pola Asuh dengan status Gizi Balita di kota dan Kabupaten Tangerang Banten. Proseding Penelitian Bidang IImu Eksaskta 2011.

8. Edris Melkie, Assessment of nutritional status of preschool children of Gumbrit, North West Ethiopia, Ethiop.J.Health Dev; 21 (2). 2007.

9. Sari Endah Purnama, Hubungan tingkat pengetahuan ibu dengan Status Gizi Balita di Posyandu Wijya Kusuma RT 04, Geblagan, Tamantirto Kasihan Bantul, Skripsi FKIK UMY diakses pada www.digilib.fk.umy.ac.id/gdl.php?mod=browse\&op=read\&id=yoptumyfkpp-gdlendahpurna-575 diakses pada tanggal 12 November 2012

10. Kusumaningrum N.R., dan Wiyono V.H., Pengaruh Tingkat Pendidikan lbu, Aktivitas Ekonomi Ibu dan Pendapatan Keluarga Terhadap Status Gizi Balita di Kecamatan Simo, Kabupaten Boyolali, JPP; 3 (2):105 - 125, 2003.

11. Marjan. Z. M., Kandiah. M., Lin. K. G. and Siong.T.E., Socioeconomic profile and nutritional status of children in rubber smallholdings, Asia Pacific J Clin Nutr,11(2): 133-141, 2002. 
